\title{
A Dialogic Classroom: Facilitating the Interaction on Cross-Taiwan-Strait Issues Regarding the Reconceptualization of the Evolution of Marxist Theories
}

\author{
Chih-Feng Chien (Corresponding author) \\ College of Education \& Human Development, Texas A\&M University \\ 1402C East Circle, College Station, TX, 77840 \\ Tel: 1-682-564-4077Ｅ-mail: iorifeng@tamu.edu
}

Received: September 28, 2010 Accepted: January 10, 2011 doi:10.5539/ies.v4n2p3

\begin{abstract}
With regard to the evolution of Marxist theories affecting the relationship between China and Taiwan historically and conceptually, this paper starts with the conceptual framing of the general evolution of Marxist theories-Marxism, neo-Marxist, and post-Marxism. Through dialectical and reconceptualized practice and learning the development of modern Taiwan in the evolutionary modes of Marxist theories, the relationship between China and Taiwan is interpreted as an ambiguous pattern which has evolved from Marxism, neo-Marxism, to post-Marxism. The purpose of this paper is not focused on Marxist theoretical work, but instead, to provide the concentrated themes - the suggestions of creating a dialogic classroom in three curricular methods - currere approach, critical theory, and postmodernism. The paper will conclude that in a debate over China-Taiwan-relationship issues, both sides will imperatively recognize the historical past, focus on the present moment, and have the prospect of a future with mutual benefits.
\end{abstract}

Keywords: Marxism, Neo-Marxism, Post-Marxism, China-Taiwan relationship, Dialogic classroom, Currere approach, Critical theory, Postmodernism

\section{Introduction}

As China moves toward political reforms, emancipation of mind and the most important economic blooming, it has become world's second largest economy. Unlike as rigid as previous image of being a stereotype communist, plausibly the world views China focusing on economic growth not on thought control and dictatorship. China has seemed changing its stereotype appearances of poverty, laggard, and dictatorship, and exceeding world's expectation to stand on the edge. In addition, different from what China represented with distorted Marxism, transformed Leninism, and autocratic Maoism, it is now equivalent with those positive descriptions of advance, transition from the old to the new, integration between Eastern and Western, and burgeoning and strong economic system. On the other side, Taiwan, with totally different rule system-democracy, freedom, and modernization-has been synchronized with advanced countries since the 80 's period. China has used to oppress Taiwanese seeking for international allies for diplomatically isolating Taiwan. Until recent, the conflicts seem to mitigate after China economically grows and a number of trade agreements have been signed for more cross-strait interflow on various prospects. The purpose of this article is to apply the evolutionary modes of Marxist theories-Marxism, neo-Marxism and post-Marxism - to retrospect the relationship between China and Taiwan and to suggest the mutual beneficial way of creating a facilitating dialogue. This paper is organized with the beginning of introductions of three evolving Marxism patterns (section 2) and the following of how they are applied in Taiwanese-and-China Relationship according to historical and contemporary perspectives (section 3). Three curricular methods-currere approach, critical theory and postmodernism-will be amalgamated into the intended dialogue (section 4). The conclusion of retracing the past, examining the present and envisioning the future of both sides will be given in the final section. The stricture of the paper is attempting to answer two questions:

(1) How do the evolutionary modes of Marxism develop in the relationship between China and Taiwan?

(2) How to establish a neo-Marxist/post-Marxist classroom for the dialogue of political issues between Taiwan and China?

\section{Literacy of Marxist Theories}

\subsection{Marxism}

Marxism is the political philosophy originally derived from the works of Karl Marx and Friendrich Engels during 
the $19^{\text {th }}$ century labor movement in Europe. The ideology is built mainly upon the idea of dialectical materialism in which the natural resources of a society determine what the society will produce and what type of society it will be. Marx believed "society prior to the individual for man becomes truly human and self conscious only through his fellow-men" (Jordan, 1971, p. 11). Marxism relates to the political practices of the communist state that can be seen in Leninism, Trotskyism, Maoism, and revolutionary socialism. These radical philosophical concepts based on Marx and Engles' works had been misinterpreted in pernicious effects. With the impacts of German classical philosophical ideology, British political economics, and French utopian socialism, the theoretical structure of Marxism consists of Marxist Philosophy, Marxian Economics, and Scientific Socialism. Although various forms of Marxism exist based on the differences of cultures and backgrounds of the world, Marxism and its branches share some similar principles: 1) capitalism is based on the exploitation of workers by the owners; 2) the material conditions dominate people's consciousness; 3) the different relations of production cause the stratified classes; 4) the material conditions and social relations are historically malleable; 5) class struggle and evolving conflicts between classes construct historical periods and drive historical changes; 6) in the historical process, the deconstruction of former class structure of society results in the replacement of new construction of current class structure.

Classical Marxism, expounded to a great extent by Karl Marx and Friedrich Engels, includes the rejection of exploitation of the labors, the critique of capitalists' extortionate profits, and the analysis of political economy, social theory and historical materialism. However, due to communism notorious for its restraint of freedom and putrefaction of dictatorship, Marxism which grounds the basis for communism turns out to be "demonized" thoughts. In the late $19^{\text {th }}$ and $20^{\text {th }}$ centuries, the drastically political changes in number of countries generated from the Marxist thought were obviously not the ideal communist society in Marx's original ideology. Because of some misinterpretation and misapplication, Marx even declared in his late life with anguish and disappointment that he was not a Marxist (Cummins, 1980, p. 6). It has been concluded by Ollman (1976) that Marx was ignorant of the elementary factors of social life within the confined and impoverished European mainland during the $19^{\text {th }}$ century to account for such gross misrepresentation. Thomas (2008) once marked that "the fact remains that Marx was misrepresented in a specific way that has had, and continues to have, detrimental effects on his reception" (p. 33). The misinterpretation of Marx's thoughts is the origin of Orthodox Marxism which indicates the version of Marxism after the death of Marx, such as Leninism, Maoism or Kautskyism.

Some scholars, nonetheless, work hard to safeguard authentic Marxism. White (1996) argues that Russian dialectical materialism did not derive from Marx's own words. On the other hand, he suggests that Marx's theory should be questioned and ruminated so as to apply in genuinely historical phenomenon and new conditions, and then continually being re-thought, adapted, and changed. Instead of defending the originally positive concept of classical Marxism and differentiating from orthodox Marxism, Marxists should go through more analytical and synthetical processes to develop Marxism as a living philosophy, through the route by which neo-Marxism was developed.

\subsection{Neo-Marxism}

With the putative preconception of communism and exegetical inconsistencies of the Marx's thought, Marxism has been criticized as being ambiguously either positive or negative unified political movements. Gorman (1982) argues that "Marxism means different things to different people, and hence, is a discontinuous movement supporting a heterogeneous clientele" (p. ix). Even though Marxist theories have been evolved and utilized by multidisciplinary subjects and heterogeneous theoretical concepts, Levine and Lembcke (1987) pointed out that Marxist theoretical work is developed through cycles, energized by the growth of revolutionary movements and integrated with practical work of social change. With the annexation of Max Weber's social inequality and socioeconomic conception, political ideals (freedom and justice), and philosophical approaches (ontology, epistemology, ethics, feminism, critical theory, liberalism, etc.), neo-Marxism has emerged in the $20^{\text {th }}$ century. Attempting to supplement the perceived deficiencies of orthodox Marxism and dialectical materialism, Neo-Marxism adds Max Webber's socioeconomic conception and begets the new and amalgamative theoretical approaches, such as Hegelian-Marxism, Critical Theory, Analytical Marxism, and Structural Marxism. Neo-Marxism is distinguished but originated from orthodox Marxism that has strategic relevance for social transformations. Levine and Lembcke (1987) argued that "in this process, the holistic and dialectical properties of Marxist methodology were lost, and basic Marxist concepts like class and exploitation were either discarded or reinterpreted" (p. 4). If Marxism is considered a self-explanatory theoretical concept as a revolt reflecting against industrial revolution in the $19^{\text {th }}$ century, neo-Marxism can be perceived as pluralistic dialogue to shift the paradigm as it stood apart from orthodox Marxism and classical liberalism. Gorman (1982) addressed that "contemporary neo-Marxism is a living dialogue of antagonistic perspectives, less united than leftists presume and potentially more attractive than rightists imagine." The rejuvenation of Marxist thought-neo-Marxism, is primarily extracted from the internality of the history of Marxism. 
With the application of Weberian theory, the new discovery is understanding the mechanisms for social transformation from capitalism to socialism in light of not only exploitative and oppressive views, but also analytic and diagnostic perspectives. In this period, "humanism, empiricism, voluntarism, eclecticism, and idealism were now explicit and proudly displayed" (Szymanski, 1987, p. 33). Some examples of theories derived from neo-Marxism in the meanwhile are state theory, urban and labor studies, dependency theory, critical theory, and so on. In the dependency theory, a differentiation between Marxism and neo-Marxism could be seen according to Leaver's (1983) analysis. He addressed that Marxism was the concern to analyze the laws of tendency within the pure capitalist mode of production, while neo-Marxism was the investigation of the contemporary form of the capitalist world system and the manner in which this system constrains and involutes the development of the periphery (Leaver, 1983). Neo-Marxism has moved beyond capitalism which was established by proletarian revolution. In dependency theory, though neo-Marxism concentrated on dominant nations - core countries and Third World nations as periphery countries, Gulalp (1983) suggested that we look at neo-Marxism as a socialistic concept to achieve both national and international development.

\subsection{Post-Marxism}

During the 1980s, following the events of the collapse of the Soviet Union and Eastern Europe, and Tiananmen Square protests for democracy of China, Marxist political commitments and theoretical approach have been strongly disputed and criticized. Laclau and Mouffe (2001) aggressively promoted the construction of post-Marxism for an alternative as they stated that "we are now situated in a post-Marxist terrain." The pretext for Laclau and Mouffe's defense was that "it is no longer possible to maintain the conception of subjectivity and classes elaborated by Marxism, nor its vision of the historical course of capitalist development, nor, of course, the conception of communism as a transparent society from which antagonisms have disappeared" (Laclau \& Mouffe, 2001, p. 4).

Docherty (1996) also points out that on the basis of post-Marxism, Marxism itself becomes part of the problem, not part of the cure. He argued that the institutionalization of Marxism impedes the inoculation of critical changes and revolutionary practices in which he promoted post-Marxism to maneuver critical procedure and phenomenological deconstruction. Howarth (1998) discussed four ways to define post-Marxism. First, post-Marxism might refer to thinkers and bodies of thought which have been influenced by Marx's writings. Second, it could designate those writing in Marxist style after Marx. Third, it might define those writers who have explicitly identified themselves as post-Marxists. Fourth, it might represent an ideal to strive after post-Marxism. Post-Marxism emerges to some extent as a political theory based on Laclau and Mouffe (2001)'s criticism that classical Marxist theory could not explain the behavior of political struggles and socio-political or economic classes. Bowman (2007) continues that classical Marxism throughout the $20^{\text {th }}$ century has been challenged based on its political force and intellectual viability. The challenges include Marxist credibility as a political position and as an academically plausible paradigm.

Post-Marxism could also be considered a theoretical approach to vindicate Marx by referring the principal foundation from Marx's and Marxist's writings. Goldstein (2005) gave an additional remark that "some of these post-Marxists preserve the normative force of Freudian, Hegelian, or critical theory and justify thereby the radically democratic articulations, translations, or potential hegemony of oppositional or independent movement. Other post-Marxist emphasize the sociohistorical context of modern discursive practices, not the ideals of theoretical critique, and as a result open these practices to political critique" (Goldstein, 2005, p. 21).

Unlike classical Marxism which defends class struggle and provokes proletarian revolution, Post-Marxism reveals the struggles of sexual, racial, and ethnic division of modern social life and promotes progressive transformation. In the $1980 \mathrm{~s}$ and $1990 \mathrm{~s}$, the new form of the social struggles gradually moved from proletariat to middle class. McLaren and Farahmandpur (2005) indicated that capitalism in the current period is not necessarily endangered by the ethnic, racial, gender or sexual identities of the social group. They concluded Wood's view of Marxist analysis and stated that "capitalism can survive antiracist and anti-sexist practices because it is a social system based on economic exploitation and the ownership of private property" (McLaren, \& Farahmandpur, 2005, p. 24). Consequently, the social groups such as environmentalists, feminists, gays and lesbians, and peace activists, may and do entice social struggles that result in new forms of social movements, such as Second National People of Color Environmental Leadership summit in 2002, Massachusetts Legalizes Same-Sex Marriage in 2004, etc. As Goldstein (2005) says, "Laclau's post-Marxism dismisses not only Stalinist communism or bureaucratic working-class organization but all establish progressive groups, including trade unions, left-wing political parties, and women's, African American, ethnic, or gay organization and programs" (p. 64). As a result, the ideologies of liberalism, radicalism, pluralism and democracy have been proposed. An example was that Laclau and Mouffe initiated the term "radical democracy" in their Hegemony and Socialist Strategy. As Mouffe (2005) expressed that 'radical and plural democracy' visualized the extension of democracy to a wide range of social relations. What he 
means is to "reinscribe socialist goals within the framework of a pluralist democracy and to insist on the necessity of their articulation with the institutions of political liberalism" (Mouffe, 2005, p. 90). Howarth (1998) elaborated on the perspectives of radical democracy for Laclau and Mouffe in that it "consists of the extension of demands for freedom and equality in ever greater spheres of society" (p. 135).

Post-Marxism, to some extent, resembles postmodernism focusing on literary, political and social philosophy, history, human nature, pluralism, differences, and oppression groups. Docherty (1996) addressed that "postmarxism, like postmodernism, strives to make the possibility of thinking - of an unpoliced, undisciplined thought, or of thinking differently-available once more" (p. 245). Overall, post-Marxism is the theoretical approach that is used to impart postmodern perspectives on historical, aesthetic, multicultural, pluralistic and philosophical discourses. In addition, according to Goldstein (2005), post-Marxism theory "advocate(s) a new hegemonic bloc of independent black, women's, ethnic, gay, or trade union movements" (p. 111). More precisely, it overtly supports the progressive organizations and "effectively promotes the progressive transformation of Western social life" (Goldstein, 2005, p. 113).

\section{Evolving Marxism Patterns Appling Taiwan-and-China Relationship}

\subsection{Marxism in China}

As Marx and Engles (1848/1948) stressed in Manifesto of the communist party, "the history of all hitherto existing society is the history of class struggles," the history of modern China and the Chinese Communist Party is the episode of aggressive socioeconomic development practiced by peasants, literally representing Marx's (1965, p. 78) urbanization of the countryside. Undergoing the oppression of the domestic feudal reign and the persecution of the alien capitalistic powers in the mid-nineteenth century, China was gradually becoming a half-feudal and half-colonial society. In the early $19^{\text {th }}$ century, with the prevalence of liberal and western tendencies, active students in China launched the May fourth Movement (Bergere, 2000) which grounded the base of the Chinese Communist Party. "In China, Marxism scored a major victory in 1949 when Mao Tse-Tung established the People Republic of China based on Marxist principles" (Gutek, 1995, p. 294). According to Pfeffer (1976), "the thought of Mao Tse-Tung involves the application of Marx's epistemology, modes of analysis, and concepts like class struggle, the division of labor, and the dictatorship of the proletariat to Chinese experience in order to comprehend and change Chinese reality" (p. 421). The authentic Marxist thoughts, however, did not arrive in China at this time. On the contrary, "among most western students of Chinese communism it is something of a truism that Marxism came to China in its Leninist form" (Meisner, 1971). Mao borrowed Marx's idea of intellectuals and leadership elite in order to build up and strengthen his sovereign status as well as to agitate the peasant revolt as his ideology of proletarian revolution. The contradiction was that at that time during the early $20^{\text {th }}$ century, China was not in the material and industrial accomplishments of capitalism, which made Maoism as the non-Marxism and non-Leninism. Mao utilized the recruitment of peasants to engage in the rebellion against alien capitalistic colonialists and Kumintang (KMT or Chinese Nationalist Party). The ideology of Marxism and in that, the idea of proletarian revolution, purports to fulfill the abolition of private property. The end of the proletarian revolution according to Marxian study, is supposed to be the vision of the communist utopia. "Marxist theory prophesies mankind's leap from the realm of necessity to the realm of freedom," (Meisner, 1982, p. 6) "in which the free development of each is the condition for the free development of all" (Marx, \& Engels, 1848/1948). However, Marxism misinterpreted by Mao turned China into totalistic communistic country where national authority and economy are controlled by a single party, and citizens are in equal impoverishment and have in the restriction of speech and criticism. Walder (1977) pointed out Mao's conception reveals relative paucity of observable research into Marx's and Marxists' writing. He continued that "a dominant theme presents Leninism as a degeneration from original Marxism, and Maoism, in turn, as further degeneration from Leninism" (Walder, 1977). Eventually, Mao's distorted form of Marxism developed a capitalist-type economy, such as the Great Leap Forward, Steel Production project, and Surpassing UK and US project. Mao's inconsistency of Marxism expanded the stigma of communism essentially as well as defamed orthodox Marxist for those who do not comprehend true Marxist theory. He manipulated Marxist thought in the form of peasant revolt turning to be violent movements, in which the patriarchal social system stood still in primitive stage, large number of peasants were killed, civilians remained impoverished, and the Communist Party of China (CPC) centralized national-wide thought, wealth, and public speech. Although Maoism has been criticized as distorted and aberrant form of Marxism, Mao successfully adopted Marxist-Leninist ideology to Chinese condition in which he could be considered the intellectual heir.

\subsection{Neo-Marxism in Taiwan}

Due to Mao's persistence of abolition of bureaucratic capitalism and his unwillingness to give up the liberation army force, a Chinese Civil War between Soviet-supported CPC and western-supported KMT broke out and lasted for more than 20 years (1927-1950). A large number of people, over 3.2 million were killed. This includes casualties 
from the civil wars both before and after World War II (Scaruffi, 2009). KMT was defeated and retreated to Taiwan. During the $20^{\text {th }}$ century, Taiwan, as Shrensen (2007) described, had been through Japanese colonial rule which left it with advantageous and strong infrastructures, productive agriculture techniques, and a population with a comparatively high level of education. Furthermore, the USA's willingness to assist Taiwan in economic development and in the confrontation with communism during the cold war demonstrated that the democratization had taken root on the island. Taiwan acted as a representative territory and a defense of western democratic countries during the cold-war period. "The Republic of China on Taiwan was the island fortress in the US crusade against Communism" (Liu, 2007). Taiwan along with Singapore, South Korea, and Hong Kong, is known as one of the "Four Asian Tigers." This categorization for Taiwan, established the so-called "Taiwan Miracle." From the early stage of the one-party rule of the KMT to the present multi-party governmental system, the democratic prospect distinguishes Taiwan significantly from mainland China.

On the aspects of politics, economy, culture and society, the development of Taiwan tied the relationship with China, to some extent to dependency theories, on which neo-Marxists have concentrated constantly. The approaches of dependency theories consist of core industrialized countries (e.g., the USA, the UK, and those $20^{\text {th }}$ century north capitalistic countries) and peripheral non-industrialized countries (e.g. Latin American countries, African countries, and the early $20^{\text {th }}$ century south-east Asian countries). In the application of Marxism, the capitalism prototype used by core developed countries has been imposed upon peripheral underdeveloped countries. "In particular, the core industrialized countries were experiencing growth and economic development through the exploitation of the non-industrialized peripheral countries" (Willis, 2005, p. 69). Frank (1967) termed this phenomenon as a "development of underdevelopment." As the marginal role played for centuries, Taiwan has had maintained peripheral status or territory for China in the historical context. Under Qing dynasty's ruling for more than 200 years, "Taiwan was a rather wild and wooly frontier area on the Chinese periphery" (Davison \& Reed, 1998, p. 10). After Japanese colonial reign, Taiwan with democratized politics and liberal economic development, has established infrastructures in terms of agriculture, technology, education and civilization. Its development overtook China and escaped out of the framework dependency theories interpret. Although neo-Marxists, like Frank, believed that "within capitalism the peripheral regions of the world would always be exploited and marginalized," "capitalist style development was impossible for peripheral countries within the existing system and was challenged by the economic success of the newly-industrializing countries of Asia during the 1970s" (Willis, 2005, pp. 70-72). Neo-Marxism, the approach full of critiques and challenges, claims the existence of such evidence of Taiwan's experience refuting the basic approaches of dependency theories.

Neo-Marxism goes in-depth to interpret Marx's concrete expression of reason in the Hegelian sense. Gorman (1982) argued that "Marx favored democratizing political life, including disestablishing state religions, equalizing citizens' right, and universalizing suffrage-allowing everyone to participate meaningfully in political activities, and hence, realizing the state's essence" (pp. 72-73). By focusing on Hegel's dialectical idealism, neo-Marxism adds Max Weber's social inequality, such as power, status and wealth, to understand individual value, to be self-conscious of the importance of freedom, to be dialectic on idealism and materialism as a whole, and to recognize social democracy and economic dynamism (Solimano, 1998) as the tendencies to propel postmodern epoch. I believe that the democratized and flourishing economic development in Taiwan is burgeoned under the high likelihood of the conception of neo-Marxism.

\subsection{China-Taiwan Relationship in Post-Marxism Perspectives}

In 1971, the Republic of China (ROC or Taiwan) made a clean division from the People's Republic of China (PRC). ROC as one of the founding members of the United Nations decided to withdraw from the UN. Ever since, it has not returned to UN and an ambiguous situation has remained between non-independence and non-unification. In the application of existential phenomenology, the relationship between China and Taiwan parallels with De Beauvoir's ambiguity concept. Similar to what De Beauvoir argued, China, a utilitarian certainty, tends to disregard ambiguity, ignore individualism, and place people on the side of generality (Slattery, \& Morris, 1999, p. 25), while Taiwan, a democratic ambiguity, tends to recognize each person's freedom, treat each person as an individual subject, and values each person as a human being (p. 27). Neo-Marxist's values of liberalism and critical theory might correspond with De Beauvoir's recognition of ambiguous freedom, but might also be ambivalent with Sartre, as Noddings (2007, p. 73) interpreted, who accepted the classical Marxism that freedom of existentialism could not be fully exercised under oppressive political condition.

As CPC has grown strongly in the contexts of economy and armed force in recent decades, its potential intimidation, dominate hegemony, and hostile confrontation menace Taiwan in terms of apprehension of CPC's force invasion and the decline of Taiwan's international economic strength and allied relationship. However, with the paradigm shift from a totalitarian communist system to the current tendency of democracy as well as from Marxist's radical 
proletarian revolution to neo-Marxist's reconstructive hermeneutics, Taiwan gradually obtained incremental international recognition and advocacy. This resembles what critical hermeneutics acquires inspiration from neo-Marx.

The social and political objectives of hermeneutics are to deconstruct hegemonic power arrangements and create individual liberation from oppressive class structures. Critical hermeneutics deconstructs economic systems and social metanarratives by challenging false consciousness in order to uncover the ideological nature of beliefs and values (Slattery, 2006, p. 132)

The methodology of critical hermeneutics is similar with the approach of post-Marxist theories. According to Slattery (2006), the goal of critical hermeneutics is to promote distortion-free communication and a liberating consensus, as well as to accomplish in politics, religion, aesthetics, education, and psychology a consensus beyond ideology. This corresponds to above-mentioned post-Marxist method to import postmodern perspectives on historical, aesthetic, multicultural, pluralistic and philosophical discourse. Post-Marxism in the intellectual perspectives plays counteractive role to resist and oppose against authoritarianism and totalitarianism. Sim (2000) stated that post-Marxism as a political force is to overthrow the classical Marxism and reorient current commitments to cultural pluralism and liberalism. Since Taiwan has been free from Japanese colonization, Taiwan with democratic thought, liberal conception, and multicultural ideology as opposed to China with restricted human rights and single-party ruling reveals an extreme contradiction and disparity. The paradigm shift where formidable authority and absolute certainty are rejected and suspected becomes the tendency of current commitment. The deconstruction of democracy-and-communism through ideal communication "will deliver truth and engender significant nonlinguistic emancipation and liberation" (Slattery, 2006, p. 132). The following section will continue discussing how to develop an objective and harmonious dialogue on the issues between Taiwan and China in classrooms in the application of neo-Marxist and post-Marxist theoretical methods.

\section{Critical Political Pedagogy: Neo/ Post-Marxist Dialogue on Political Issues in the Classroom}

The critical pedagogy applied with neo-Marxist and post-Marxist theories to engage students in the dialogue on political issues of the cross-Taiwan-strait relationship need to involve with prolpetic experience, critical theory and postmodern curriculum. As materialism had been articulated by Karl Marx, historical methodological explanation could not be ignored when looking for causality of political developments, societal changes, ideological transformation, paradigm shift, and social reproduction. Proleptic experience, as Slattery (2006) stated, leads us to listen to the past in order to attune to the future and illuminate the present time. Critical theory, derived from the work of theorists of Frankfurt School, has both linear and circular relationship with neo-Marxism and post-Marxism. In addition, postmodern curriculum provides deconstructive and hermeneutic conceptions to support students in identifying politics in a variety of contemplative, creative, complex and philosophical ways. The following is the elaboration of three methods of developing a political-pedagogy classroom in the way of neo-Marxism and post-Marxism.

\subsection{Currere Approach}

The way to introduce students to the political changes and developments on the relationship between China and Taiwan and lead them to experience proleptic moment has to focus specifically on historical events, present diplomacy, and future progress. William Pinar's (2004) currere method has perfectly fulfilled this curricular approach. This method, as explained by Pinar (2004), is the Latin infinitive form of curriculum which means to run the course, or the gerund form, the running of the course. The currere approach "provides a strategy for students of curriculum to study the relationship between academic knowledge and life history in the interest of self-understanding and social reconstruction" (Pinar, 2004, p. 35). This method consists of four steps or moments: the regressive, the progressive, the analytical, and the synthetical. Applying to developing a political dialogue regarding the China-Taiwan relationship is perfectly matched with proleptic experience. In the regressive stage, the instructor has a time frame to begin from the events in the middle of the $20^{\text {th }}$ century, such as the civil war between CPC and KMT, Mao's claim of control of the mainland, Chiang Kai-Shek's withdrawal to Taiwan with two million refugees and soldiers, and Chiang's plans to reclaim the mainland; the events across the second half-century, such as Cultural revolution, China on the Rise, the relationship between CPC and KMT with the United Nations (UN), Martial Law in Taiwan, Tiananmen Square protests, and democratic development in Taiwan; and to the recent events after the millennium, such as the commotion that arose in Tibet and Xinjiang over independence. The instructions could be imparted by every individual event through a variety of methods, such as lecturing, presentations, the watching of videos, documentation reviewing, and historical field trips. The purpose of the regressive stage is to inform students of the historical events between China and Taiwan and present them the progress of history without imposing any subjective judgment. In the progressive stage, the instructor leads students to concentrate on what is 
not yet the case and what is not yet present. As Pinar (2004) suggested, "the future inhabits the present" (p. 36). On the basis of the regressive experience, students are encouraged to look at what is happening between China and Taiwan, and imagine what will happen in the future. With global economic crisis occurring during 2008 and 2009, China has been playing a dominant role reacting strongly and effectively to deal with financial recession in the investment of infrastructural constructions and domestic trading networks. The economic rise of China is causing major changes in cross-strait relationships in terms of cultural interflow, political intercommunication, military interaction, and mutual policies. The China-Taiwan relationship has turned from threatening military face to economic and technological interdependence. The proleptic manner used by instructor here is to inform students of the current China-and-Taiwan news in response to global tendency and to envision the future as a whole for the next step, which is to analyze. In the third step of analysis, students are to examine the past, present, and future from the previous two stages by using the method of deconstruction and decontextualization. Pinar (2004) pointed out that "the analytic phase is not self-scrutiny for the sake of public performance, a self-theatricalizing in which social life becomes a spectacle," and continued that "the point of currere is an intensified engagement with daily life, not an ironic detachment from it" (p. 37). Students analyze the historical events, current occurrences and future potentials on the topic of China-Taiwan relationship through listening to inner voice and external opinions. The purpose of this stage is to encourage the complicated conversation, as Pinar (2004) annotated, which should be more open-ended, sometimes rather personal, and interest-driven event in which persons dialogically encounter each other. A critical but objective mindset and a challenging but harmonious atmosphere are extremely important when conducting complicated conversation. In those conditions, we should be able to reach the synthetical stage. In the moment of synthesis (Pinar, 2004), or prolepsis (Slattery, 2006), self-knowledge and collective analysis from the cognition of past, present and future form the inspired amalgamation. Students who either support China or Taiwan exterminate the hostility, transcend linear historical segmentation, prompt cooperative enthusiasm, understand the importance of reciprocal benefits, and reach the essence of reconceptualized political curriculum for ultimate social reconstruction.

\subsection{Critical Theory Approach}

Critical theory is the essence of neo-Marxism and post-Marxism, in which it plays the role of analysis and criticism. Torres (1999) claimed that "critical theory has not tried to delineate the future development of human interaction that it may deem most relevant for empowerment and liberation - which are indeed seen as the ultimate goals of any human experience" (p. 92). He also contended that Marxism is dead and neo-Marxism is also not a monolithic approach. "Neo-Marxism and critical theory perspectives include a call for democratic renewal, highlighting the importance of emancipatory social movements to democracy in contemporary capitalist societies" (Torres, 1999, $\mathrm{p}$. 92). With the cross-strait-relationship dialogue developed in the approach of critical theory, students are constructed with the conception of contradiction, dialectics, exploitation, domination and legitimation as related to neo-Marxism. Students with self-consciousness and critical thinking tend to believe the ultimate means for social reconstruction is democracy which, however, is an ongoing struggle for equality, freedom, and human dignity. The bridge of political reconciliation between China and Taiwan is paradigm shift and social reconstruction in which society and education are in urgent need of constant reforms and structural changes. In Patrick Slattery's "Curriculum Development in the Postmodern Era," he summarized several scholars' important works relating to elements of critical pedagogy cited from Peter McLaren and elements of critical theory cited from Jurgen Habermas. The elements of critical pedagogy includes the hidden curriculum, which refers to the studies about minorities, discrimination and forbiddance, and null curriculum, which refers to overt the aspects of curriculum that are omitted because of time constraints, omissions or prejudice of the teacher. If a teacher omits the history of Tiananmen Square Protests in China or the 228 Incident in Taiwan, the repressive and undemocratic environment would never be remembered and recognized, and students will never know the importance of democracy in order to further value it. If the Cultural Revolution in China or White Terror was never taught in the classroom, the social justice and historical judgment would never be pronounced and the people who sacrificed for reformation would never be commemorated. Another three important elements of critical theory are "technical knowledge, which can be measure and quantified; practical knowledge, which is intended to help individuals understand social events that are ongoing and situational; and emancipatory knowledge, which attempts to reconcile and transcend the opposition between technical and practical knowledge" (Slattery, 2006, p. 234). Emancipatory knowledge is extremely important for students to learn to ponder, analyze and synthesize rather than to receive, repeat and memorize. Empowering students to challenge China-Taiwan political issues and liberating them to criticize the contemporary capitalist society precisely hits the key points that the neo-Marxist classroom seeks. Critical theory plays an important role in the development of the dialogical classroom, which contributes to a micro level of improvement in self-consciousness, and further contributes to a macro level of improving the practice of policy makers, politicians, or bureaucrats. 


\subsection{Postmodern Approach}

The reason that the post-Marxist classroom needs to involve a postmodern approach is because, based on Aronowitz and Giroux (1991), postmodern criticism explicates the intellectual equality of marginal discourses - feminism, sexuality, race, class, etc. The goals of postmodern education precisely parallel post-Marxist methodology. Furthermore, Aronowitz and Giroux made a very convincible argument:

Critical postmodernism provides a political and pedagogical basis not only for challenging current forms of academic hegemony but also for deconstructing conservative forms of postmodernism in which social life is merely made over to accommodate expanding fields of information in which reality collapses into the proliferation of image. ... a critical postmodernism signals the possibility for not only rethinking the issue of educational reform but also creating a pedagogical discourse that deepens the most radical impulses and social practices of democracy itself (Aronowitz and Giroux, 1991, p. 187).

When facing the cross-strait-relationship issues, instructors utilize the postmodern approach to entice students to think differently and critically, meaning that multidimensional lens relating to the issues need to be included and further interpreted. For example, there is an immense difference existing in the political and economic systems between China and Taiwan. Prior to debate for what the appropriate political interaction is, students need to understand the difference between governmental systems - the democracy of Taiwan and the communism of China, and of the economic system - the market economy of Taiwan and the planned economy of China, as well as both sides' 50-year development and changes. Curriculum needs to be constructed in accordance with radical democracy and fundamental equilibrium. Moreover, the dialogical classroom moves beyond rigid disciplinary structures toward flexible trans-subjective and inter-subjective structures. The purpose of developing the dialogic classroom is to exchange the difference between both sides in the searching for the creation of social and political space in which both sides represent broader tolerance, acceptance, appreciation and plurality. Post-Marxist classroom pursues to reformulate these struggles and oppressions for justice, equality, freedom and sustainability. It also encourages us to rethink the relations between the centers and the margins of power. The objective of this dialogic classroom is to look for a way to overcome the historical misunderstanding, complex differentiation, ideological boundaries, and democratic struggle between China and Taiwan.

\section{Conclusion}

McGee (1997) cited from Laclau and Mouffe to argue that post-Marxism involves the renunciation or negation of Marxism's conceptual ambitions. Referring to David Booth, Corbridge (1990) also claimed that post-Marxism, rejecting the epistemological baggage of classical Marxism, "opens the way to an intellectual and practical world view which emphasizes a careful exchange of ideas and a progressive politics of the possible" (p. 624). My paper perceives the post-Marxism classroom integrating with proleptic, critical-theory, and postmodern curriculum approaches on the dialogue of China-and-Taiwan issues as an ultimate goal. In the paradigm shift process, Marxian ideology of freedom of individual and equality under capitalism is inclined to be critiqued by neo-Marxist and post-Marxist critical analysis and current world-wide democratic prevalence necessitates deconstructing hegemonic structure. This kind of neo-Marxism/post-Marxism classroom prospects to facilitate the interaction between China and Taiwan to a rational and objective status in accordance with democracy and social justice. Analogues to the application of Pinar's (2004) assertion of intellectual opportunities, the creative tactics used by the classroom are to engage students into political curriculum as it takes the forms of historical, phenomenological, postmodern, autobiographical, aesthetic, international, and institutionalized.

\section{References}

Aronowitz, S., \& Giroux, H. A. (1991). Postmodern education: Politics, culture, and social criticism. Minneapolis, MN: the University of Minnesota Press.

Bergere, M. (2000). Sun Yat-Sen (J. Lloyd, Trans.). Palo Alto, CA: Stanford University Press.

Bowman, P. (2007). Post-Marxism versus cultural studies: Theory, politics and intervention. George Square, Edinburgh: Edinburgh University Press Ltd.

Corbridge, S. (1990). Post-Marxism and development studies: Beyond the impasse. World Development, 18(5), 623-639

Cummins, I. (1980). Marx, Engels and national movements. New York, NY: St. Martin's Press.

Davison, G. M., \& Reed, B. E. (1998). Culture and customs of Taiwan. Santa Barbara, CA: Greenwood Press.

Docherty, T. (1996). After theory. George Square, Edinburgh: Edinburgh University Press. 
Frank, A. G. (1967). Capitalism and underdevelopment in Latin America. London: Monthly Review Press.

Gutek, G. L. (1995). A history of the western education experience. Long Grove, IL: Waveland Press, Inc.

Goldstein, P. (2005). Post-Marxist theory: An introduction. Albany, NY: State University of New York Press.

Gorman, R. A. (1982). Neo-Marxism: The meanings of modern radicalism. Westport, CT. Greenwood Press.

Gulalp, H. (1983). Frank and Wallerstein revisited: A contribution to Brenner's critique. In P. Limqueco, \& B. McFarlane (Eds.), Neo-Marxist theories of development. New York, NY: St. Martin's Press, Inc.

Howarth, D. (1998). Post-Marxism. In A. Lent (Ed.), New political thought: An introduction. London, UK: Lawrence \& Wishart Limited.

Jordan, Z. A. (1971). Karl Marx: Economy, class and social revolution. New York, NY: Charles Scribner's Sons.

Laclau, E., \& Mouffe, C. (2001). Hegemony and socialist strategy: Toward a radical democratic politics. Brooklyn, NY: Verso.

Leaver, R. (1983). Simir Amin on Underdevelopment. In P. Limqueco, \& B. McFarlane (Eds), Neo-Marxist theories of development. New York, NY: St. Martin's Press, Inc.

Levine, R. F., \& Lembcke, J. (1987). Recapturing Marxism: An appraisal of recent trends in sociological theory. New York, NY: Praeger Publishers.

Liu, P. (2007). Queer Marxism in Taiwan. Inter-Asia Cultural Studies, 8(4), 517-539

Marx, K. (1965). Pre-capitalist economic formations. New York, NY: International Publisher.

Marx, K., \& Engels, F. (1948). Manifesto of the communist party/by Karl Marx and Friedrich and Engels; authorized English translation edited and annotated by Friedrich Engels. New York, NY: International Publisher. (Original work published 1848)

McGee, D. T. (1997). Post-Marxism: The opiate of the intellectuals. Modern Language Quarterly, 58(2), 201-225

McLaren, P., \& Farahmandpur, R. (2005). Teaching against global capitalism and the new imperialist: A critical pedagogy. Lanham, MA: Rowman \& Littlefield Publishers, Inc.

Meisner, M. (1971). Leninism and Maoism: Some populist perspectives on Marxism-Leninism in China. The China Quarterly, 45, 2-36

Meisner, M. (1982). Marxism, Maoism and Utopianism: Eight essays. Madison, WI: The University of Wisconsin Press.

Mouffe, C. (2005). The return of political. Brooklyn, NY: Verso

Noddings, N. (2007). Philosophy of education. Cambridge, MA: Westview Press.

Ollman, B. (1976). Alienation: Marx's conception of man in capitalist society. New York, NY: Cambridge University Press.

Pfeffer, M. (1976). Mao and Marx in the Marxist-Leninist tradition: A critique of "The China Field" and a contribution to a preliminary reappraisal. Modern China, 2(4), 421-460

Pinar, W. F., (2004). What is curriculum theory? Mowah, NJ: Lawrence Erlbaum Associates.

Scaruffi, P. (2009). Wars and genocides of the $20^{\text {th }}$ century. [Online] Available: http://www.scaruffi.com/politics/massacre.html (July 9, 2009)

Shrensen, G. (2007). Democracy and democratization: Process and prospects in a changing world (p. 45). Boulder, CO: Westview Press.

Sim, S. (2000). Post-Marxism: An intellectual history. New York, NY: Routledge.

Slattery, P. (2006). Curriculum development in the postmodern era. New York, NY: Routledge, Taylor \& Frances Group.

Slattery, P. \& Morris, M. (1999). Simone De Beauvoir's ethics and postmodern ambiguity: The assertion of freedom in the face of the absurd. Education Theory, 49(1), 21-36

Solimano, A. (1998). Social inequality: Values, growth, and the state. Ann Arbor, MI: University of Michigan Press.

Szymanski, A. (1987). Crisis and vitalization: An interpretive essay on Marxist theory. In R. F. Levine, \& J. Lembcke (Eds.), Recapturing Marxism: An appraisal of recent trends in sociological theory. New York, NY: Praeger Publishers. 
Thomas, P. (2008). Critical reception: Marx then and now. In T. Carver (Ed.), The Cambridge companion to Marx. New York, NY: Cambridge University Press.

Torres, C. A. (1999). Critical theory and political sociology of education: Arguments. In T. S. Popkewitz, \& L. Fendler (Eds.), Changing terrain of knowledge and politics. New York, NY: Routledge.

Walder, A. G. (1977). Marxism, Maoism, and social change. Modern China, 3(1), 101-118

White, J. D. (1996). Karl Marx and the intellectual origins of dialectical materialism. New York, NY: Macmillan Press Ltd.

Willis, K, (2005). Theories and practices of development. New York, NY: Routledge. 